\title{
How to Evaluate and Judge When the Moral-Educational Dimension of Instruction Is Concerned?
}

\author{
Mojca Kovač Šebart ${ }^{1}$ \\ ${ }^{1}$ Faculty of Arts, Department of Educational Sciences, University of Ljubljana, Slovenia \\ Correspondence: Mojca Kovač Šebart, Department of Educational Sciences, Faculty of Arts, University of \\ Ljubljana, Aškerčeva 2, SI-1000 Ljubljana, Slovenia. Tel: 386-40-452-061. E-mail: \\ mojca.kovac-sebart@guest.arnes.si
}

Received: March 6, 2015 Accepted: April 24, $2015 \quad$ Online Published: July 24, 2015

doi:10.5539/res.v7n11p138 URL: http://dx.doi.org/10.5539/res.v7n11p138

\begin{abstract}
The text examines the question of what value framework moral education in the public school of a democratic, multicultural society can legitimately rely on. The Constitution of the Republic of Slovenia and education legislation establish the concept of human rights (and duties) as the fundamental ethical and legal norm in Slovenia. From the aspect of legality and legitimacy, the concept has been established as the normative basis that must also be followed with regard to moral education in public schools. The author argues (and provides two practical cases as illustrations) that the right of parents to educate their children in accordance with their religious or philosophical beliefs does not require public school to avoid addressing "contentious" topics, although they may cause children moral distress. The only thing that public school must ensure is for knowledge to be transmitted objectively, critically, and pluralistically, and guarantee that there is nothing that could lead to indoctrination. This means that school and teachers must not impose any views on children about which people differ or require them to identify with a particular viewpoint. Rather, they must express the differences very clearly and allow for the co-existence of and respect for different views.
\end{abstract}

Keywords: human rights, moral education, public school, syllabus, value framework

\section{Introduction}

This article sets out to answer two questions: what value framework should moral education in the public schools of a democratic, multicultural society rely on, and how should public schools, but in particular their teachers, act in practice within that framework? Furthermore, the article examines two related practical cases that illustrate the issues that teachers and schools face in everyday educational practice in Slovenia.

We live in a society where different traditions come together and where there is no monolithic set of values. The amalgam of different traditions is even more complex because of society's multiethnic nature. "In a society in which there is a plurality of traditions," Haydon writes, "persons cannot live simply within one tradition as self-contained; to some degree they must also live with other traditions and with the persons who inhabit those traditions" (Haydon, 1987, p. 6). Kymlicka (1995, p. 4), referring to Galston, emphasizes that in a democratic society people should possess "the willingness to listen seriously to a range of views which, given the diversity of liberal societies, will include ideas the listener is bound to find strange and even obnoxious." This means that people must provide reasons for their demands and should do so in a way that will allow them to persuade those of different faiths or worldviews. In a democratic society it is not enough, Kymlicka writes, to attempt to persuade others of the general acceptability of our own particular demands by invoking "Scripture or tradition" (ibid.). Citizens must justify their demands in terms that their fellow citizens will understand and accept on the supposition that they are approached as free and equal—not as inferior simply because they do not share the worldview or faith of the person addressing them. They must make an effort to distinguish clearly between private beliefs and values and the beliefs they defend publicly; at the same time, however, they must be able to ask themselves how their public beliefs and standpoints look from the point of view of those belonging to different religions, traditions, or worldviews (ibid.).

In response to these issues, the following questions are raised: What are the values from which and with which we can address fellow citizens holding other faiths, worldviews, or philosophical beliefs? Is there a system of shared values that could justifiably be claimed as a possible value guideline for moral education in public schools? How 
should schools address the indisputable influence of instruction on the formation of values and their transfer to students? How to act in public school, where values and actions among students as well as those of students and teachers are incompatible? The solutions to these dilemmas are anything but simple.

The fact that we live in a society where different traditions come together and where there is no monolithic set of values - in Western societies, the complexity of traditions is heightened by their multiethnic nature - signals very clearly that moral education cannot transmit the values of only one of the various cultural traditions, since that would require a decision about which tradition should be chosen (Haydon, 1987; Hill, 2006). This dilemma, of course, does not at all indicate that it is possible to avoid dealing with values in school.

\section{One of Teachers' Tasks Is to Encourage Dialogue}

A possible course of action originating in the pluralism and particularity of values is represented in encouraging the position of non-interference in other people's actions, even if we morally disagree with them (ibid., p. 56). By necessity, this position soon confronts problems that are purely practical in nature and cannot be avoided merely by recourse to non-interference in others' standpoints or actions. Neither can such problems be avoided by demanding that schools educate by teaching independent thinking and decision making, so that people would be able to choose from among all the values offered by the set of different traditions (ibid., p. 4). A critical reflection upon inherited values has, in fact, already become part of the modern tradition of Western societies, so we should be capable, in the same breath, of explaining why we favor that specific tradition.

The proposal that dialogue is a key to the solution of practical problems at the elementary level involves similar issues. According to Haydon, some people believe that the only acceptable values are those "which will survive critical and fair dialogue" (ibid, p. 6). Waldron (1993) adds the dimension of debate, and simultaneously shows the inadequacy of dialogue and debate. Earnest and respectful discussion and dialogue are, needless to say, good and unavoidable: "If I disagree with you about the existence of God, I may put forward my arguments, but I must do so in a way that is circumspect and inoffensive, taking full account of the fact that your religious beliefs are not just your views, but convictions which go to the core or essence of your being. I must be sensitive to the role these beliefs play in your life, and not deal with them lightly, sarcastically, or insultingly" (ibid., p. 138).

Such an approach, Waldron emphasizes, combines the values of truth seeking with the principle of respect. It leaves room for debate, but it avoids mockery, offense, and insults. Most of all, it enables us to understand the notions that relate to convictions as principles and that embody "what we owe to one another as humans, in respect for deeply held convictions" (ibid.). Nonetheless, the author gives a word of warning: although, at the elementary level, dialogues open up possibilities for resolving dilemmas over different value orientations, the inadequacy of dialogue becomes apparent very quickly at the moment when discussions and debates no longer concern us only at the rational level. To illustrate the point: certain individuals are so ardent about their beliefs that they perceive even the most sober and respectful criticism as an insult to their personality. Waldron (1993) maintains that the predicament can be solved if we accept the fact that experiencing distress at others' answers to what concerns us is part of the price of entering into dialogue (ibid., pp. 138-139). For that reason, he continues by stating that persons and peoples must leave one another free to address the questions of religions, philosophies, convictions, etc. as best they can, although others' positions may cause them distress (ibid., p. 140). Or, as the author vividly illustrates his point: "In the modern world that may mean that the whole kaleidoscope of literary technique - fantasy, irony, poetry, wordplay, and the speculative juggling of ideas - is unleashed in what many regard as the holy, the good, the immaculate, and the indubitable" (ibid.). Waldron concludes that this is surely not an easy ideal to live with: "Things that seem sacred to some will in the hands of others be played with, joked about, taken seriously, taken lightly, sworn at, fantasized upon, juggled, dreamed about backward, sung about, and mixed up with all sorts of stuff" (ibid, p. 141). In short: "There is no other way we can live together and respect each other's grappling with life" (ibid., p. 142).

The message is unambiguous: contradictions and value conflicts in society and in schools are impossible to prevent. The position that identifies dialogue, "free discussion" and respect for each other's grappling with life as the way out of the particularity of values and beliefs is, therefore, inadequate for a viable conception of moral education in public schools. Public school education is focused not on adults but students, who are not yet fully formed subjects. The problem thus re-establishes itself through the following questions: How should educational activity proceed if we presume "the conflict of values and judgments"? What should it adopt as a basis for dialogue? What principles of action should it follow when dialogue is not possible, when there is no willingness for it? How can teachers enable the treatment of problems which are not "value neutral" without stigmatizing or excluding anyone in public school? What should teachers do when dialogue leads to unacceptable outcomes (e.g. students may agree that foreigners are a menace)? How is it possible to 
evaluate and judge when the moral-educational dimension of instruction is involved?

\section{Consensus on the Values of Civilized Society}

Because students require guidance in value orientation, it is necessary to seek consensus in society on what we can adopt as common from the particular value systems existing in a given period, thereby establishing the fundamental system of values on which instruction in public schools should be based (Kovač Šebart, 2002, pp. 70-71). The current consensus on the fundamental values that apply irrespective of particular political and value systems is represented by the rights contained in the Universal Declaration of Human Rights from 1948 (United Nations Organization, 2012), the European Convention on Human Rights from 1950 (European Court of Human Rights Council of Europe, 2012), the Convention on the Rights of the Child from 1989 (Office of the United Nations High Commissioner for Human Rights, 2012) and several other international documents. The signatory states that ratified the Convention for the Protection of Human Rights and Fundamental Freedoms (Council of Europe, 1994), in which it is the highest/constitutional legal act, accept that the concept of human rights (and duties) is the fundamental ethical and legal norm. From the aspect of legality and legitimacy, the concept is also the normative basis that must be followed with regard to moral education in public schools. The European Dimension of Education: Teaching and Curriculum Content (1989, pp. 3-5) cites human rights, pluralistic democracy, tolerance, solidarity, and the rule of law as the common European heritage of the political, cultural, moral, and spiritual values on which a civilized society is based. Through the adoption and inclusion of these values in the Universal Declaration of Human Rights from 1948 (United Nations Organization, 2012), its authors wished to prevent any particular value system from attempting to assert its values as universal in the public education system.

It is vitally important to stress that the concept of human rights involves values such as refraining from stealing and lying, exercising tolerance, and helping those in need. Even the concept of human rights, by protecting rights, presumes and imposes duties. For example, the right to life imposes the duty not to kill (Article 3 of the Universal Declaration of Human Rights: "Everyone has the right to life, liberty and security of person"), the right to property imposes the duty not to steal (or, as Article 17 of the Declaration states: "No-one shall be arbitrarily deprived of his property"), and the directive "do not lie" (or, expressed positively, "tell the truth") asserts the rights that guarantee "a fair trial," etc. (United Nations Organization, 2012). In other words, the concept of human rights represents a component of the set of values that are comprised by the majority of individual value systems, about which there is consensus regarding their universality at a given moment. In other words, human rights are not derived from only one ideological system; rather, they combine the best of what different moral and value systems have produced (Hall, 1988, p. 4) and about which consensus exists that at a given time they are the best and the most universally acceptable. In this way, the rules, values, and norms considered common are established through social consensus; in public schools, their starting point is enabling a form of coexistence in which instruction excludes no one and favors no one. Through them, schools establish the framework for evaluation and dialogue (Kovač Šebart, 2002, pp. 71-72).

\section{The Ethics of Human Rights: A Basis for Moral Education in Public Schools?}

The concept of human rights (and duties) incorporates the foundations of contemporary social morality. It also incorporates them through that which specific rights include in their contents. Namely, these rights and duties protect the basic conditions of the civilized existence of humans as inherently social beings, thus enabling the coexistence of the specificities of dominant and minority social norms. And, finally, the concept of human rights is the foundation of the social ethical principles that require us to act in specific ways in relation to others (Berlin, 2002).

On the one hand, such ethical principles represent a universal social norm, providing protection against anyone interfering with the individual's personal integrity in the areas that constitute the foundation of humanity and human existence. Realizing these principles is possible only if each individual respects the same rights of others, because rights are valid only inasmuch as they are implemented by society, the state, and each individual in his or her individual actions in the form of duties toward others.

Rights are always and necessarily also our duties toward others, since the concept of rights includes the presupposition and requirement of their respect. In other words, the social conception of the relationship between rights and duties is initially based on the fact that concrete duties deriving from the rights of others impose actions whose norms are not established by the individual, because the content of these duties is socially determined. Therefore, moral education aimed at students' recognition of the norms and values included in human rights must - similarly to the awareness of one's own rights and corresponding actions - impart the awareness of one's responsibilities toward others and of the appropriate actions deriving from the contents of 
universally valid rights. Moreover, we could suggest that moral education committed to the ethics of human rights and aiming at their social implementation must first commit us to the duty of respecting the equal rights of others (Kovač Šebart \& Krek, 2007, pp. 17-18; Kovač Šebart \& Krek, 2009; 2010).

For instance, the right defined within the concept of human rights as the right to life simultaneously imposes the duty defined in the Judeo-Christian tradition as one of the Ten Commandments ("Thou shalt not kill"). The right to possession implies the duty of not stealing. The Commandment "Thou shalt not bear false witness against thy neighbor" (i.e. "speak the truth") is the underlying assumption of the concept of the rule of law and the rights guaranteeing fair trails. In the concept of human rights, the Commandment "Honor thy father and thy mother" is translated into the universal right to non-discrimination, which at the personal level imposes the responsibility to respect everyone, irrespective of their personal characteristics, etc. (Kovač Šebart \& Krek, 2009, pp. 89-90).

Perhaps a certain difference in the structure of duties lies in the fact that the obligations (duties) which have been imposed in some religious traditions on the person in relation to God (not just on the person in direct relation to another person) are assumed in this context irrespective of the relationship between humans and God. These duties exist in themselves within the framework of the relation of one person to other people or-even more importantly - to the dignity of other people's personalities. Nonetheless, it is evident that in terms of their basic contents traditional moral duties do not contradict the duty to one's fellow people imposed by the principle of the same humanity of everybody. This is the foundation of all rights and, by extension, modern ethics. It commands tolerance, which is certainly related not only to the right to non-discrimination but to the duties toward others that originate in such elementary rights as the right to life, and to the duties originating in the rights to freedom of thought and debate as well as religion and conviction. Moreover, social ethics are a precondition for social cohesion in the modern world, where differences and disagreements will unavoidably arise. The status of social ethics in modern society is primarily justified by its content—by the ethics of human rights (ibid., p. 91; Kahne \& Sporte, 2008).

This means that human rights as fundamental value matrices of the contemporary era should be established as a solid reference point, an unambiguous point of certainty, from which the moral-educational actions of public schools derive and on which they are based. These very principles of human rights and duties, that is, enable the coexistence of diversity. That is why the principles are a necessity that should be followed in schools. In terms of values, moral education in public schools should give the student orientation, but not just any orientation - value guidance should impose duties and actions derived from rights that insist on respect for every person irrespective of the differences among people.

\section{5. "Critical Morality"}

One of the educational tasks of public schools is encouraging students to internalize the values and norms defined by the European Dimension of Education (1989) as the shared heritage of values, to recognize them as their own, or, to put it otherwise, to accept them as part of their convictions and actions - as part of their moral characters. The common value framework does not concern only political power and the legal regulation of the state. Nor does it concern only the philosophical and pedagogical concepts with which we could support professionally the agreement on common values and norms, and thus provide teachers with a recipe for their actions (Kovač Šebart, 2002, pp. 73-75). In his analysis of John Stuart Mill's On Liberty (1992), Waldron (1993, p. 136) emphasizes that Mill "addresses it to his fellow citizens, not their government, because he was sure the threat to individuality and freedom came from society 'executing its own mandates' rather than from the agency of the State." In order "to protect freedom of thought and debate," Mill argued for "a strong barrier of moral conviction" (ibid.).

In addition, Mill's concept raises the question of who influences the dominant convictions in a society and in what manner. The issue of establishing "a strong barrier of moral conviction" definitely requires more than the convictions of individuals. This new dimension enables an entry into the area of the problem that goes beyond enumeration, dialogue, and conscious will. It does so by attempting to address the subject of our own convictions and actions. The question is whether the individual internalizes certain values during the educational process and acts in accordance with them, since the internalization of the value symbolic matrix is the first condition for the perception of their controversy (cf. Martin, 2011; English, 2011). Let us illustrate this thesis very briefly with one of the formulations of Kant's categorical imperative. In his Critique of Practical Reason, Kant (1909), formulates the fundamental law of the pure practical reason - the so-called fundamental moral law-with the following words: "Act so that the maxim of thy will can always at the same time hold good as a principle of universal legislation" (Kant, 1909, p. 119). Yet what need is there for the guiding principle of moral judgment and actions, and why should its formulation be so abstract and general? 
The difficulty of moral judgment and action, as Kant underscores it, is that individuals, as autonomous and rational beings, a priori find themselves in a moral dilemma. There are circumstances, to be sure, when deciding what is good and what is bad, despite the fact that the individual is presumed to hold firmly adopted beliefs, cannot be simple or straightforward for the subject of these beliefs. Critical morality begins with the realization that as an individual and value-defined subject I am capable, in the same situation, of different judgments, decisions, and actions, all of which can be considered moral. The concept of the categorical imperative introduces into the field of morality the warning that in moral judgment and decision making it is necessary to ask whether one's considerations, decisions, and actions can have universal validity, so that they can apply as a principle, and to ask how they would pass critical judgment (my own and that of others).

If we desire to educate individuals capable of "critical morality" and moral reflection, individuals who enact the right to freedom of thought and debate, then it is not enough to teach students about the existence of different views and their supporters and familiarize them with how to critically confront ethical judgments that oppose each other. The integration of rules, the internalization of the symbolic matrix, must also be achieved.

It is true that we are unable to dictate educational activities whose direct effect would be the internalization of values and, therewith, the provision of autonomous guidance on ethical judgment, which would allow for a dilemma when facing values in a space open to reflection and debate. But if we desire students to become (internally) committed to specific values as well as to gain the ability to reflect upon their own integration in the symbolic network, these goals have the best chance of being realized in the conditions of freedom of thought and debate. The ability to take a critical attitude toward reality develops in a space that gives students assistance and value guidance, but at the same time lets them face or even confront some of their convictions, values, knowledge, or judgments.

\section{The Criteria of "Objective, Critical, and Pluralistic Instruction" and the Question How to Educate}

Thus far we have been concerned with the question of what value framework should form the basis of moral education in public schools. Now, we turn to how public schools, and especially teachers, should act concretely within these frameworks. How should educational activity be conducted if we presuppose the conflict of values, knowledge and judgment?

Human rights as a norm place certain requirements on teaching; these requirements bind Slovenia as a signatory of the Convention for the Protection of Human Rights and Fundamental Freedoms (1994), hereafter referred to as Convention, with regard to its attitude toward human rights. In this respect, the Convention also binds all Slovenian educational institutions. In addition to obligations, it offers certain answers (Kovač Šebart, 2002, p. 156). The provision of the second sentence of Article 2 of the First Protocol of the Convention is particularly relevant as regards the questions posed above. It states: "In the exercise of any functions which it assumes in relation to education and to teaching, the State shall respect the right of parents to ensure such education and teaching in conformity with their own religions and philosophical convictions." The European Court of Human Rights and, previously, the European Commission of Human Rights have already made judgments in several cases relating to this right of parents (Digest of Strasbourg Case-Law, 1985, pp. 743-828). Hence, a number of general interpretations of the right have been made, stating that respecting the right does not mean that in public schools the state should guarantee moral education in accordance with parents' wishes. The state must allow children to receive such education in private schools, but the state is not obliged either to establish or finance them. Public schools, on the other hand, must realize the right by precluding indoctrination, which means, among other things, that educational contents (which can contain religious or philosophical connotations) must be addressed in an objective, critical, and pluralist way (Kodelja, 1995, pp. 23-24; Meredith, 1992; Digest of Strasbourg Case-Law, 1985).

The criteria of objective, critical, and pluralistic instruction can also be adopted as guiding principles for decision making in conducting instruction. In fact, Slovenia's education legislation has adopted and incorporated them as a norm in the School Inspection Act (1996). The Act stipulates that evidence must be taken from an expert in education if, inter alia, "the circumstances reveal facts that lead to the conclusion [...] that teachers and other professionals have failed to ensure objective, critical and pluralistic instruction in carrying out educational work" (ibid., Article 8). The Act, therefore, sets the three criteria as the norm for conducting educational work in general, including instruction in the school classroom as well (Kovač Šebart, 2002, p. 77).

The criteria discussed above also have consequences for the issue of "critical morality." Respecting the criteria of objective, critical, and pluralistic instruction provides answers to ethical questions, because of which "the ethical" no longer appears to be self-evident. Differences in the answers imply reflection, which often leads the student into ethical dilemmas. In other words, a child can be morally distressed in public school precisely 
because of respect for the above-mentioned criteria (Krek \& Šebart, 1999, p. 129). As the interpretations of the European Court of Human Rights show, the norm of respecting human rights does not require public schools to shrink from discussing potentially controversial topics. Respect for the criteria of objective, critical, and pluralistic instruction binds schools and the teachers - first, to objectivity, that is, to impart knowledge based on science, with the knowledge that the student acquires in this way the basis of criticality; and second, to a pluralism of values and convictions, which is a social reality that must be reflected in school instruction. Hence, it becomes apparent that it is crucial to differentiate (and accustom students to do so) between knowledge and values, between expertise and convictions (beliefs), between facts and opinions (ibid., p. 78).

\section{Analysis of Two Practical Cases from Slovenia}

In the end, the issues that teachers and schools have to deal with in their everyday educational practice will be illustrated with two examples.

Knowledge assessment, for instance, is a fine example where the distinction must be rigorously enforced. Since knowledge assessment implies coercion and public schools must protect the right to individual convictions (beliefs), public schools can only assess objectively verifiable and demonstrated knowledge, rather than individual convictions, opinions or values (Kovač Šebart 2002, p. 78).

During a part-time studies course at the Faculty of Education, University of Ljubljana, with the students having considerable practical pedagogical experience, a participating teacher posed the following question - and offered the response:

"What should the teacher do when his/her explanation of the origins of life on the Earth is challenged by some students' support for the biblical story of Adam and Eve? Or, even tougher, when the teacher asks a student the question during knowledge assessment and the students insists on his/her creationist view? There seem to be various possibilities, such as

1) sanctioning (with a negative grade), thereby asserting unconditional authority - the teacher's personal authority as well as the authority associated with the institution of school;

2) A lengthy argument, attempting to bring the two seemingly irreconcilable views to a common denominator;

3) Giving up any further debate, saying it is not that important after all.

It is, of course, clear from the very beginning and without any need for further discussion, that the happy mean is the sensible approach." (Kovač Šebart \& Krek, 2009, p. 166)

The consideration for the principles of critical, pluralist and objective instruction proves the categorical answer wrong. The proposed solution to the dilemma about knowledge assessment expressed above ("a lengthy argument, attempting to bring the two seemingly irreconcilable views to a common denominator"-instead of a grade) is highly problematic because - to remain entirely consistent - these two answers to the question about the origins of life cannot be equalized, i.e. brought to the same denominator, since one of them is based on theology and the other one on scientifically supported theories. The difference, therefore, is between scientific and theological argumentation, which is unbridgeable. Consequently, the student should be explained that we are faced with two quite different discourses and answers.

Taking into consideration the principles established in this text and the subsequent standpoint that the teacher must not assess beliefs or convictions, but only demonstrated knowledge defined by the educational goals and knowledge standards in valid syllabuses, we reach the conclusion that the student's belief in the creation of the world as presented by a religious community cannot be assessed. On the other hand, the teacher may require the student to have and demonstrate the knowledge he/she should possess according to the educational goals and knowledge standards set by syllabuses. Hence, if the teacher requires the student to know and satisfactorily reproduce the explanation of the origins of life based on scientific foundations and to cite the scientific theories of renowned experts, thus demonstrating expected knowledge, knowledge assessment (even if the grade is negative) does not mean that the student cannot hold on to his/her own beliefs. The status of particular convictions and beliefs is up to each individual, yet at the same time public schools have to insist on knowledge and the aim according to which students should achieve the required knowledge standards. They may be "morally distressed" (see also Waldron, 1997), they may be encouraged to approach the issues critically, this being exactly what the criteria of "objective, critical and pluralist instruction" imply. Moreover, by teaching the student how to be objective, pluralist and critical, they produce long-term integration effects (ibid.).

Let us now move on to the other case. Three years ago Roman Kuhar, a colleague from the Faculty of Arts, 
University of Ljubljana, had to face an unpleasant surprise. He was supposed to be a visiting lecturer on the topic of different families in a Slovenian primary school. The syllabus, in fact, specifies that educational content for children aged 10 and 11 years. Having a twenty-minute talk in mind, he prepared some illustrations of traditional, foster, reorganized, single-parent, and same-sex families. All the materials had been approved by the teacher and presented to parents. Two or three parents protested, with one threatening that his child would be banned from attending the lecture if it included a discussion of same-sex families. Kuhar discussed the situation with the teacher and decided to cancel the talk, believing it would have been pointless to bang his head against the wall, knowing that, as a consequence, a child might be hurt. But the story continues. Subsequently, one student's mother invited him to talk about families at her home. Thirty-two parents and children attended, and they had an informative and entertaining Friday evening class.

Although this may seem a sensible solution - and it was the only possible one for Kuhar, who was invited to the school as a guest - it was, from the perspectives of the goals that mandatory public school must pursue, highly problematic and completely unacceptable. First, the content that the three parents found objectionable was planned to be presented during a mandatory education program and in accordance with the syllabus of the school subject "Society." The then-valid syllabus for the fourth-grade subject "Society," in which Kuhar was supposed to participate as an expert, had the thematic unit "Family-Types of families, changes in family life" (Syllabus ... Society, 2006, p. 9), with suggested topics including a discussion of different types of families (ibid., p. 10). The operational objectives of the subject included the explicitly stated goal of "students recognizing types of families" (ibid., p. 10).

It is also important to emphasize that the then-valid syllabus for the first-grade primary-school subject "Learning about the environment" (Syllabus ... Learning about the Environment, 2005) included families and the varieties in families as suggested topics in the content unit "I, you and we" (ibid., p. 9). The operational objectives included the goal specifying that students should "recognize different forms of families and develop a tolerant attitude toward them" (ibid.).

The proposed discussion of same-sex families opposed by a handful of parents was clearly part of the syllabus for the subject "Society" in the fourth grade of primary school. The goals stated in curricula bind teachers as they plan and conduct the teaching process. Therefore, they must not and cannot avoid the topic, although it may be objectionable to some (or many) parents, teachers, or students. In other words, education in public school can oppose parents' particular values. In Slovenia, the point at which public schools may begin to disregard the right of parents to educate their children in accordance with their own convictions is formally defined by the Constitution of the Republic of Slovenia, other national legislation, school curricula, and international human rights legislation.

A similar conclusion can be drawn from the decisions made by the European Court of Human Rights: respect for human rights does not require public schools to avoid addressing "contentious" topics. For instance, when the Danish government introduced mandatory education about sexuality in lower-primary public-school grades, some parents filed a complaint. The Court, however, decided that the state must only ensure that knowledge be transmitted objectively, critically, and pluralistically and that public schools renounce anything that could lead to indoctrination. This means that schools and teachers must not impose on children or require them to identify with any views on which people differ. Rather, they have to express the differences very clearly and allow for the coexistence of and respect for different views. If the two conditions are fulfilled, as they were in the case of Denmark, the decision of the Court seems unambiguous: the state, by introducing the topics, and schools, by discussing them, do not infringe the right of parents to educate children according to their own religious or philosophical convictions. There is, therefore, absolutely no need for children's absences to be excused because their parents find certain educational contents "contentious" (Kodelja, 1995, p. 23; Meredith, 1992).

For that reason, instruction in public schools should avoid both the indoctrination of students, which could oppose the values and convictions of their parents, and the logic according to which some parents could assert their particular values, thereby interfering with expert decisions on what educational contents teachers should address in school (as well as how they should do it) when attaining educational objectives. Put otherwise, public schools simply cannot allow for supposedly disagreeable topics to be discussed in Friday evening classes in private apartments instead of public school classrooms.

The issues we have addressed in this paper may be predominantly theoretical, but they, nevertheless, have important practical implications. Therefore, the mechanisms that enable and assure the monitoring and evaluation of the practical aspects of moral education are of the utmost importance: not only the instructional process itself, but also the relations between students and teachers, teachers' responses to fundamental moral 
issues and dilemmas, their ability to implement the principle of objective, critical, and pluralistic instruction while dealing with the contents about which students may have different opinions are all dimensions that should be given careful attention and remain continuously assessed.

\section{References}

Berlin, I. (2002). Two concepts of liberty. In H. Hardy (Ed.), Liberty (pp. 166-217). Oxford: Oxford University Press. http://dx.doi.org/10.1093/019924989X.003.0004

Council of Europe. (1994). Convention for the protection of human rights and fundamental freedoms. Retrieved December 11, 2012, from http://conventions.coe.int/treaty/en/treaties/html/005.htm

Digest of Strasbourg case-law relating to the European Convention on Human Rights. (1985). Koeln, Berlin, Bonn, München: Carl Heymanns Veerlag KG.

English, A. (2012). Critical Listening and the Dialogic Aspects of Moral Education: J. F. Herbat's Concept of the Teacher as Moral Guide. Educational Theory, 61(2), 171-189. http://dx.doi.org/10.1111/j.1741-5446.2011.00398.x

European Court of Human Rights Council of Europe. (2012). European Convention on Human Rights. Retrieved November 12, 2012, from http://www.echr.coe.int/NR/rdonlyres/D5CC24A7-DC13-4318B457-5C9014916D7A/0/Convention_ENG.pdf

Hall, A. J. (1988). Liberalism. London: Paladin Grafton Books.

Haydon, G. (Ed.). (1987). Education and values. London: Institute of Education, University of London.

Hill, V. B. (2006). Values Education in Schools Issues and Challenges. Perth: Murdoch University Hill. Retrieved October 25, 2012, from http://www.valueseducation.edu.au/verve/_resources/ve_acsa_paper.pdf

Kahne, J. E., \& Sporte, S. E. (2008). Developing Citizens: The Impact of Civic Learning Opportunities on Students' Commitment to Civic Participation. American Educational Research. Journal, 45(3), 738-766. http://dx.doi.org/10.3102/0002831208316951

Kant, I., \& Abbott T., K. (1909). Kant's Critique of Practical Reason and other works on the theory of ethics (6th ed.). London, New York, and Bombay: Longmans, Green, and Co.

Kodelja, Z. (1995). Laična šola: Pro et contra [The lay school: pros and cons]. Ljubljana: Mladinska knjiga.

Kovač Šebart, M. (2002). Samopodobe šole: konceptualizacija devetletke [The self-image of school: The conceptualisation of the nine-year primary school]. Zbirka Obrazi edukacije (Book collection Visages of Education). Ljubljana: Centre for Education Policy - University of Ljubljana.

Kovač Šebart, M., \& Krek, J. (2009). Vzgojna zasnova javne šole [The educational concept of public school]. Ljubljana: Centre for Education Policy—University of Ljubljana.

Kovač Šebart, M., \& Krek, J. (2007). Ali je šoli imanentno, da lahko deluje samo nedemokratično?: demokratično $\mathrm{v}$ šoli, avtonomija subjekta in Zakon [Is it immanent to schools that they can only function non-democratically? The democratic in school, the autonomy of the subject and the law]. Sodobna Pedagogogika [Journal of Contemporary Educational Studies], 58 (special edition), 30-55.

Kovač Šebart, M., \& Krek, J. (2010). The public school, values and educational discourse. Pardubice: University of Pardubice.

Krek, J., \& Kovač Šebart, M. (1999). Državljanska vzgoja, vrednote in izkustvo zloma iluzije [Civic education, values, and the experience of a breakdown of an illusion]. Sodobna Pedagogika [Journal of Contemporary Educational Studies], 50(4), 118-139.

Kymlicka, W. (1995). Education for citizenship (manuscript). Ottawa: Foundations for Moral Education.

Martin, C. (2011). Education Without Moral Worth? Kantian Moral Theory and the Obligation to Educate Others. Journal of Philosophy of Education, 45(3), 475-492. http://dx.doi.org/10.1111/j.1467-9752.2011.00821.x

Meredith, P. (1992). Government, schooling and the Law. London: Routledge.

Mill, J. S. (1992). On Liberty; and Utilitarianism. London : D. Campbell.

Office of the United Nations High Commissioner for Human Rights. (1989). Convention on the rights of the child. Retrieved December 11, 2012, from http://www2.ohchr.org/english/law/crc.htm

The European dimension of education: Teaching and curriculum content. (1989). Newsletter/Faits nouveaux. Strasbourg: Council of Europe. 
United Nations Organization. (2012). The universal declaration of human rights. Retrieved November 5, 2012, from http://www.un.org/en/documents/udhr

Učni načrt: Družba [Syllabus: Society]. (2006). Ljubljana : Ministrstvo RS za šolstvo in šport, Zavod RS za šolstvo.

Učni načrt: Spoznavanje okolja [Syllabus: Learning about the environment]. (2005). Ljubljana: Ministrstvo RS za šolstvo in šport, Zavod RS za šolstvo.

Waldron, J. (1993). Rushdie and religion and Particular values and critical morality. In Liberal rights: Collected papers 1981-1991 (pp. 134-142, pp. 168-202). Cambridge: Cambridge University Press.

Waldron, J. (1997). Mill in moralna pretresenost kot vrednota. Problemi, 35(7-8), 99-115.

Zakon o šolski inšpekciji [School Inspection Act]. (1995). Ljubljana: Uradni list RS [The Official Gazette of the Republic of Slovenia], No. 29-1827/1996.

\section{Copyrights}

Copyright for this article is retained by the author(s), with first publication rights granted to the journal.

This is an open-access article distributed under the terms and conditions of the Creative Commons Attribution license (http://creativecommons.org/licenses/by/3.0/). 